\title{
Status and population trend of chiropterans in Southern Assam, India
}

\begin{abstract}
Population survey plays an important role in understanding the census structure of any species in a particular area. Chiropterans are an important groups of mammals found almost all part of India. Chiropterans (including Mega and Microchiroptera) are important as they have ubiquitous distribution in almost all the states of India, from Kashmir to Kanyakumari and from Gujarat to Arunachal Pradesh. They play important roles in all types of ecosystems. Mega chiropterans largely help in pollination, while microchiropterans help in pest control through insectivory. To understand the population structures, the status of bat population and its trend in Cachar district (Assam) north East India was studied. A total of six species and 97 roosting sites were found over approximately 3786 square kilometer of area. The colony size of Pteropus giganteus was found to consist of 13 to 723 individuals, for Cynopterus sphinx it was recorded as 2-9 groups having 8 to 51 individuals (with group size 3 to 8 individuals), for Eonycteris spelae it was 400-600 individuals, for Pipistrellus coromandra, it was very less, as group size was found to be of 3 to 6 individuals and for Megaderma lyra the number recorded was 5 to 128 individuals. Population structure and the prevalence indicate this zone to be a potential area for maintaining a viable population of bat species. Since no prior systematic information on the Chiropteran population is available from the area, the present study will help in formulating conservation plan of the much neglected group of nocturnal mammals.
\end{abstract}

Keywords: barak valley, habitat fragmentation, megachiroptera, microchiroptera, population
Volume I Issue 4 - 2017

\author{
Rahman A, Choudhury P \\ Department of Ecology and Environmental Science,Assam \\ University, India
}

Correspondence: Choudhury P, Department of Ecology and Environmental Science, Assam University, Silchar, Assam, India, Tel +919435078296, Email parthankar@rediffmail.com

Received: June 23, 2017| Published: November 03, 2017

\section{Introduction}

India is blessed with 430 species of mammalian fauna belonging to 49 families and 185 genera. ${ }^{1}$ Northeast India encompassing seven sister states are the least explored regions of India, and is located in between Indo-Himalayas and Indo-China sub-regions, and contains 269 mammalian species harboring $62.56 \%$ of Indian's mammalian diversity. ${ }^{2}$ Megachiroptera (megabat) and Microchiroptera (microbat) are the two suborders of the order Chiroptera to which all bats belong. ${ }^{3}$ The sub order Megachiroptera (also known as old world fruit bat) has only one family; Pteropodidae which encompasses 42 genera and 166 species. ${ }^{4}$ Microchiroptera, on the other hand consists of seventeen families and are the greater group of bats (with 834 species incorporated into 137 genera) that occur from the tropics to temperate regions of the world. Microbats bear sophisticated laryngeal echolocating capability and hence orient acoustically. ${ }^{5}$

According to modern taxonomy (which is based on molecular genetic data) the order Chiroptera is divided into two suborders i. e., Yinpterochiroptera and Yangochiroptera. ${ }^{6}$ The suborder Yinpterochiropteran includes all the fruit bats that live in the old World tropics and subtropics but are not found in North and South America, except the Egyptian fruit bat of Europe. ${ }^{7}$ Five microbat families such as Rhinopomatidae, Rhinolophidae, Hipposideridae, Craseonycteridae, and Megadermatidae are also included in this newly proposed suborder. ${ }^{8}$ The remaining families of microbats are grouped under the suborder Yangochiroptera and include the bats that were previously grouped as Yinochiroptera. Yinpterochiropteran bats are herbivores and depend on vision as well as smell detection capability to find foods. ${ }^{9}$ The Yangochiropteran bats rely on laryngeal echolocation system to navigate.

The Indian subcontinent is the home of 119 different species of bats belonging to 8 families and 3 genera. ${ }^{10}$ Chiropterans are found in almost every part of India. In India they have been reported from Andhra Pradesh, ${ }^{11,12}$ Baksa district of central Assam, ${ }^{13}$ Delhi, ${ }^{14}$ Hyderabad, ${ }^{15}$ Jaisalmer, ${ }^{16}$ Jammu and Kashmir, ${ }^{17}$ Kalakad Mundathurai tiger reserve, Southern India, ${ }^{18}$ Karnataka, ${ }^{19}$ Kerala, ${ }^{20}$ Lakshadweep archipelago, ${ }^{21}$ Manipur, ${ }^{22}$ Masinagudi village, eastern part of Mudumalai Tiger Reserve, ${ }^{23}$ Meghalaya, ${ }^{24}$ Mizoram, ${ }^{25}$ Mysore city, ${ }^{26}$ Nagaland, ${ }^{27}$ Rajasthan, ${ }^{28}$ Sikkim, ${ }^{29}$ Sundergarh district of Odisha, ${ }^{30}$ Tamilnadu, ${ }^{31}$ Tripura. ${ }^{32}$ Northeast India harbours 65 bats species out of which 28 bat species have been reported from Assam. ${ }^{33}$

Barak valley is in the southernmost part of Assam located around $328 \mathrm{~km}$ away towards southeast of Guwahati city, the state capital. The area comprises three district viz., Cachar, Karimganj and Hailakandi covering an area of $6922 \mathrm{~km}^{2}$. Although the area has one wildlife sanctuary and many reserve forests including the Inner line reserve forest (the largest reserve forests of Assam), hitherto no significant study has been done on the chiropteran diversity of Barak valley. Faunal inventory acts as an important task for precise taxon-specific and area-specific conservation efforts,${ }^{34}$ the present study therefore aims to document the chiropteran fauna of Cachar district with an aim to formulate proper management strategy to conserve the species in a pragmatic way.

\section{Materials and methods}

\section{Study area}

The study in Cachar districts was done covering as many as 895 revenue villages and towns for three years (from 2013 to 2015). Cachar is one of the three districts of Barak Valley situated in the southern Assam (India), a state known for its greeneries. The district is located within $24^{\circ} 22^{\prime}$ to $25^{\circ} 08^{\prime} \mathrm{N}$ latitude and $92^{\circ} 25^{\prime}$ to $93^{\circ} 15^{\prime} \mathrm{E}$ 
longitudes, covering an area of 3786sq. km (Figure 1). Altitude varies from $39-40 \mathrm{~m}$ above sea level. Climatic condition of the area is subtropical, warm and humid. Most of the precipitation occurs from May to September, which is mainly controlled by the southwest monsoon. The district experiences very hot and humid climate during the major part of the year (April to October). Average rainfall of this area is about $2600-2700 \mathrm{~mm}$. Temperature ranges between $9-38^{\circ} \mathrm{C}$. The district is bounded by state border with Mizoram in the South, Manipur in the south-east, North Cachar Hills and Jaintia Hills in the north and in the west by Hailakandi and Karimganj districts of Assam. Silchar is the head quarter of the district and is the second most important economic centres in the state, after Guwahati.

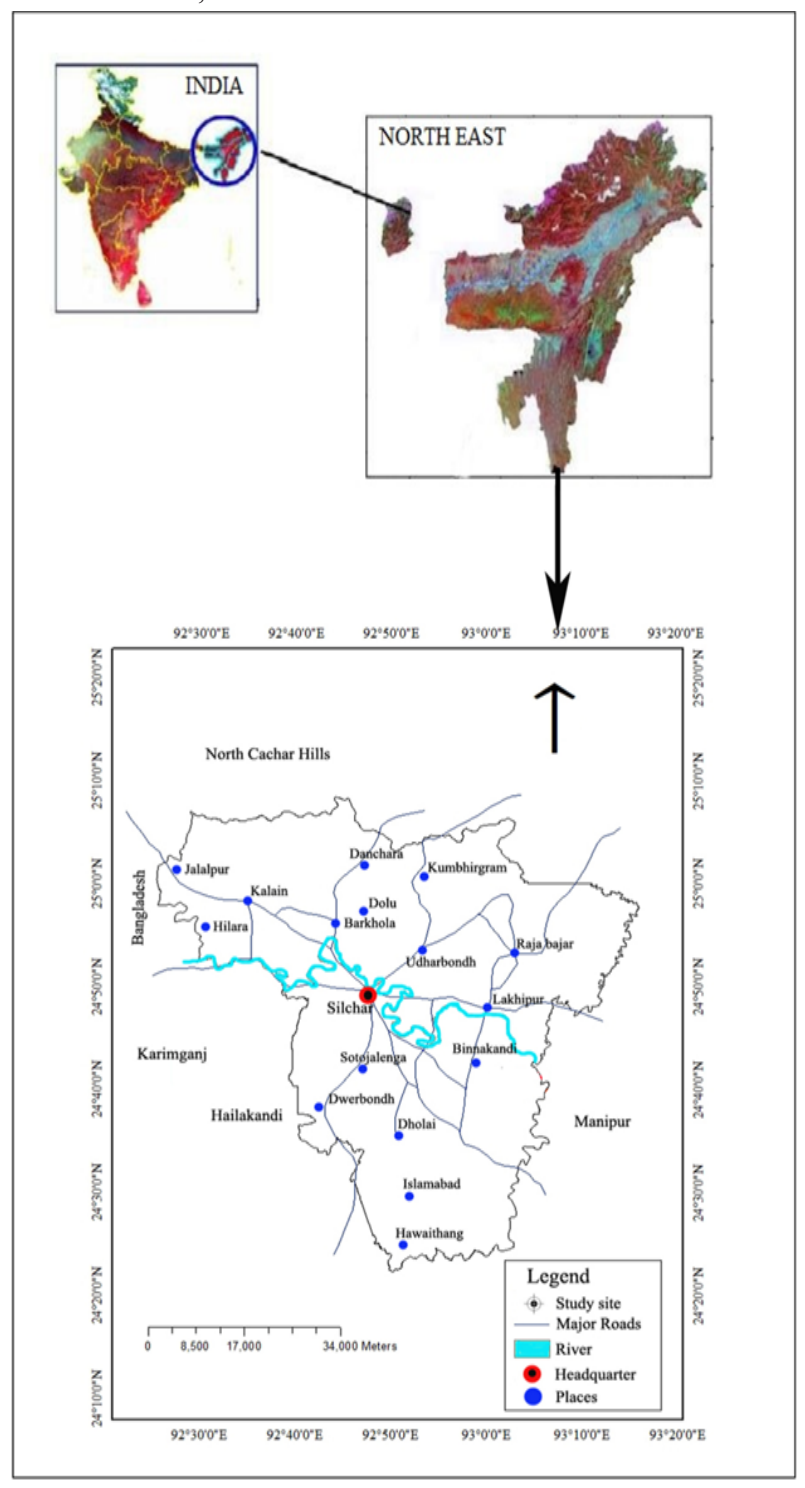

Figure I The Study area.

Survey on population status Chiropterans was conducted across the study area for three consecutive years (from January 2013 to December, 2015). Bat roosting sites were located through local enquiries in course of questionnaire survey. This was followed by extensive field survey. Periodic observations along with population count were made throughout the study area. Diurnal roosts of Pteropus giganteus, Cynopterus sphinx and Megaderma lyra were visited once in a month during the study period. Data on population status was collected during daytime preferably in the morning and evening hours. As local migration from colony to colony occurs in bat,$^{35}$ we have tried to complete the monthly population estimation for each species within 1-3 day in all roosting sites of the study area, to avoid the fluctuation in colony size due to inter-colony migration. The first week of each month were chosen for Pteropus giganteus, second weeks were chosen for Cynopterus sphinx while the third weeks were chosen for Megaderma lyra. For enclosed roosting species (Megaderma lyra) precaution was taken to minimize the disturbances. While entering the roosting place, attention was given so that minimal noise and disturbance occur. Commonly after entering the roosting area (that cause a slight disturbance) bats usually start moving haphazardly, some even exit the roosting area, thus, it is required to stay calm and quiet for about 30 minutes before counting is started. Within this period, bats get accustomed to the intruder and stop moving. Then direct numerical counting was started as per Thomas ${ }^{36}$ and Barlow $^{37}$ followed by photographic count. ${ }^{38}$ Direct numerical counting was done to count Pteropus giganteus, Cynopterus sphinx and Megaderma lyra. For small colonies, direct visual counting method was used to determine the number of individuals, while surface area estimates were made in the case of large and densely packed colonies. Binoculars were used to count of bats in colonies with inaccessible heights. Before entering each of the habitats, prior permission from the land owners was obtained, if the study site was found to be under human occupancy.

\section{Result}

The present study has documented six bat species in the Cachar district of southern Assam. The Megachiropteran species found in the study area are Pteropus giganteus, Cynopterus sphinx and Eonycteris spelaea while the microchiropteran species found in the area are Megaderma lyra, Scotophilus kuhlii, and Pipistrellus coromandra. All these species belong to two families and six genera. Among the bat species found in the area, three have been put under schedule $\mathrm{V}$ of Indian Wildlfe Protection (Act) 1972. Of these one bat have been categorized as Appendix II species of CITES. As per IUCN list of threatened species, each bat species encountered during this study period have been categorized as least concern species. Morphological features, conservation status and population trend of all the bats that are documented during the study are discussed below.

\section{Pteropus giganteus brunnich, I 782 (Indian flying fox)}

\section{Morphology}

Indian flying fox has reddish-brown fur on its head and possesses long, black and pointed ear. ${ }^{10}$ The belly is orange in color whereas the colour of the back is deep blackish brown, with a slight mixture of white hairs (Figure 2/A). The shape of the head of Pteropus giganteus is similar to a fox, after which it has been named. The blackish patagium allows covering the whole body during rain and also flip on sunny days, thus, it protects the bat from rain as well as in extreme hot condition. The forearm and head-body length of Indian flying fox usually measure $17.2-17.5 \mathrm{~cm}$ and $21.1-24.3 \mathrm{~cm}$ respectively. Body weight for males varies from 500-1600gm (Figure 2A-2F).

\section{Conservation status}

According to IUCN (Version 3.1), the Indian flying fox is categorised as least concern species. It has been categorised as the least concern species under the Red list category of IUCN (Version 2011.2) and mentioned that the population of the species is declining 
in a notable manner due to the destruction of the habitat. CITES recognised it as a species of Appendix II. As per Indian Wildlife (Protection) Act, 1972, the species falls under Schedule V. However Vendan ${ }^{39}$ marked the Indian flying fox as the conservation dependent endangered flying mammal in Southern India.
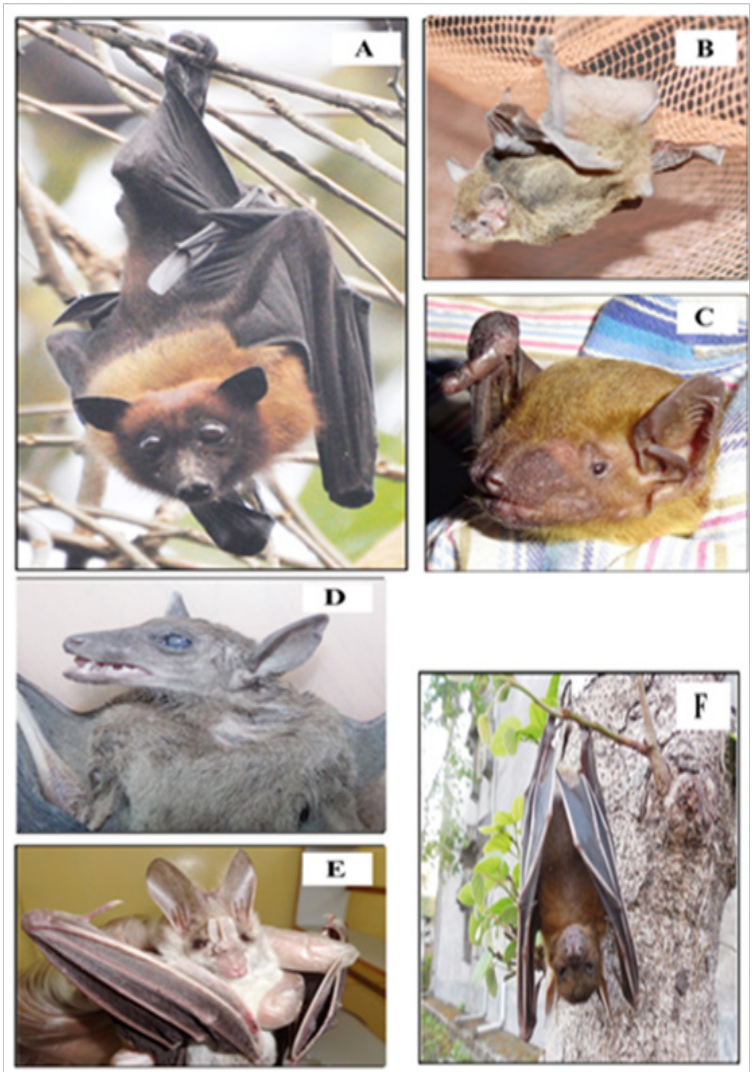

Figure 2 Bats of the study area A, Pteroous giganteus; B, Pipistellus coromandra; C, Scotophilus kuhlii; D, Eonycteris spelaea; E, Megaderma lyra; F, Cynopterus sphinx.

Table I P. giganteus observed in different sites of Cachar District

\section{Population status}

During the present study, population of Pteropus giganteus in all roosting sites was estimated which reveals 6370 individuals in the year 2013 while in the year 2014 and 2015 it was estimated to be 5403 and 5033 respectively. Mean population size of $P$. giganteus in various roosting locations of the study area during 2013-2015 was calculated as $144.77 \pm 1.72$ (mean $\pm \mathrm{SE}, \mathrm{n}=44), 122.79 \pm 1.79$ (mean \pm $\mathrm{SE}, \mathrm{n}=44)$, and $114.38 \pm 1.85$ (mean $\pm \mathrm{SE}, \mathrm{n}=44$ ) (Table 1). Maximum individuals (482) of Pteropus giganteus were observed in Dulalgram in the year 2013 while the minimum was in Hawaithang and Charmail (24). In the year 2014, the maximum number of the individual was recorded in Raninagar (560) and the minimum was recorded in Algapur (12). In the year 2015, the maximum individual counted in Raninagar (723) while the minimum was recorded for Laikon basti (13). During the study period, six roosting locations were spotted where a trend of population increase was observed while rest all sites were observed to maintain the decreasing trend. In the study area, 26 locations were documented where bats used to stay for a long time but later on left the area due to felling of roosting trees. Indian flying fox is a colonial species (Figure 2/A) and during the present study the minimum number of $P$. giganteus in a diurnal roost was recorded as 13 while maximum number was 723 individuals (Figure 3A-3C).

\section{Cynopterus sphinx Vahl, 1797 (the greater short-no- sed fruit bat)}

\section{Morphology}

This species is identified by large ears with a pale and distinct outline. It is a medium size bat having a distinct claw on the first as well as second digit, characterized by the projecting nostril. ${ }^{10}$ The adult male poses orange colour on the either side of the chest, chin, shoulder, thigh, belly and forehead whereas the female has a brown collar with a grey belly ${ }^{40}$ (Figure $2 / F$ ). The forearm and head-body length of adult Greater short-nosed fruit bat usually measure 6.4$7.9 \mathrm{~cm}$ and $7.6-11.3 \mathrm{~cm}$ respectively. The body weight for males varies from 28.0- 70.0gram and of female from 34.5-53.0gm. ${ }^{41}$

\begin{tabular}{|c|c|c|c|c|c|c|}
\hline \multirow[t]{2}{*}{ SI. no } & \multirow[t]{2}{*}{ Name of the roosting site } & \multirow[t]{2}{*}{ Geographical coordinates } & \multirow[t]{2}{*}{ Type of roosting } & \multicolumn{3}{|c|}{ Number of individuals } \\
\hline & & & & 2013 & 2014 & 2015 \\
\hline \multirow[t]{2}{*}{$\mathrm{I}$} & Algapur, Gobindapur & $24^{\circ} 46^{\prime} 49.0^{\prime \prime} \mathrm{N}$ & Irregular & 72 & 12 & 0 \\
\hline & & $92^{\circ} 52^{\prime} 51.0^{\prime \prime} \mathrm{E}$ & & & & \\
\hline \multirow[t]{2}{*}{2} & Barkhala part I & $24^{\circ} 55^{\prime} 52.0^{\prime \prime} \mathrm{N}$ & Irregular & 33 & 19 & 0 \\
\hline & & $92^{\circ} 44^{\prime} 37.4^{\prime \prime} \mathrm{E}$ & & & & \\
\hline \multirow[t]{2}{*}{3} & Baskandi & $24^{\circ} 55^{\prime} 52.0^{\prime \prime} \mathrm{N}$ & Regular & 237 & 210 & 189 \\
\hline & & $92^{\circ} 44^{\prime} 37.4^{\prime \prime} \mathrm{E}$ & & & & \\
\hline \multirow[t]{2}{*}{4} & Bethukandi & $24^{\circ} 49^{\prime} 58.6^{\prime \prime} \mathrm{N}$ & Regular & 468 & 450 & 380 \\
\hline & & $92^{\circ} 50^{\prime} \mathrm{II} .2^{\prime \prime} \mathrm{E}$ & & & & \\
\hline \multirow[t]{2}{*}{5} & Bhakatpur & $24^{\circ} 52^{\prime} 28.4^{\prime \prime} \mathrm{N}$ & Irregular & 48 & 0 & 0 \\
\hline & & $92^{\circ} 52^{\prime} 46 . I^{\prime \prime} \mathrm{E}$ & & & & \\
\hline \multirow[t]{2}{*}{6} & Boraitoli & $24^{\circ} 57^{\prime} 25.9^{\prime \prime} \mathrm{N}$ & Irregular & 78 & 54 & 49 \\
\hline & & $92^{\circ} 34^{\prime} 08.8^{\prime \prime} \mathrm{E}$ & & & & \\
\hline \multirow[t]{2}{*}{7} & Borjurai & $24^{\circ} 49^{\prime} 47.3^{\prime \prime} \mathrm{N}$ & Irregular & 34 & 23 & 18 \\
\hline & & $92^{\circ} 5 I^{\prime} 33 . I^{\prime \prime} \mathrm{E}$ & & & & \\
\hline
\end{tabular}


Table Continued.

\begin{tabular}{|c|c|c|c|c|c|c|}
\hline \multirow{2}{*}{$\begin{array}{l}\text { Sl. no } \\
8\end{array}$} & \multirow{2}{*}{$\begin{array}{l}\text { Name of the roosting site } \\
\text { Buribail Part I }\end{array}$} & \multirow{2}{*}{$\begin{array}{l}\text { Geographical coordinates } \\
24^{\circ} 52^{\prime} 51.2^{\prime \prime} \mathrm{N}\end{array}$} & \multirow{2}{*}{$\begin{array}{l}\text { Type of roosting } \\
\text { Tree cutting }\end{array}$} & \multicolumn{3}{|c|}{ Number of individuals } \\
\hline & & & & 46 & 0 & 0 \\
\hline & & $92^{\circ} 4 I^{\prime} 50.6^{\prime \prime} \mathrm{E}$ & & & & \\
\hline \multirow[t]{2}{*}{9} & Burunga Part II & $24^{\circ} 55^{\prime} 55.3^{\prime \prime} \mathrm{N}$ & Regular & 138 & 190 & 218 \\
\hline & & $92^{\circ} 36^{\prime} 07.2^{\prime \prime} \mathrm{E}$ & & & & \\
\hline \multirow[t]{2}{*}{10} & Charmail & $24^{\circ} 5 I^{\prime} 23 . I^{\prime \prime} \mathrm{N}$ & Irregular & 24 & 0 & 0 \\
\hline & & $92^{\circ} 5 I^{\prime} 02.4^{\prime \prime} \mathrm{E}$ & & & & \\
\hline \multirow[t]{2}{*}{11} & Dhanehari Part 2 & $24^{\circ} 43^{\prime} 58.8^{\prime \prime} \mathrm{N}$ & Regular & 80 & 76 & 92 \\
\hline & & $92^{\circ} 49^{\prime} 51.7^{\prime \prime} \mathrm{E}$ & & & & \\
\hline \multirow[t]{2}{*}{12} & Dolugram & $24^{\circ} 47^{\prime} 21.8^{\prime \prime} \mathrm{N}$ & Regular & 78 & 51 & 28 \\
\hline & & $92^{\circ} 56^{\prime} 38.6^{\prime \prime} \mathrm{E}$ & & & & \\
\hline \multirow[t]{2}{*}{13} & Dulalgram & $24^{\circ} 5 I^{\prime} 23 . I^{\prime \prime} \mathrm{N}$ & Regular & 482 & 426 & 430 \\
\hline & & $92^{\circ} 5 \mathrm{I}^{\prime} 02.4^{\prime \prime} \mathrm{E}$ & & & & \\
\hline \multirow[t]{2}{*}{14} & Goroirkandi & $24^{\circ} 42^{\prime} 49.7^{\prime \prime} \mathrm{N}$ & Regular & 80 & 65 & 48 \\
\hline & & $92^{\circ} 57^{\prime} 40.0^{\prime \prime} \mathrm{E}$ & & & & \\
\hline \multirow[t]{2}{*}{15} & Gosaipur Part I & $24^{\circ} 5 \mathrm{I}^{\prime} 13.5^{\prime \prime} \mathrm{N}$ & Irregular & 34 & 0 & 0 \\
\hline & & $92^{\circ} 5 \mathrm{I}^{\prime} 00.2^{\prime \prime} \mathrm{E}$ & & & & \\
\hline \multirow[t]{2}{*}{16} & Gumra & $24^{\circ} 58^{\prime} 38.6^{\prime \prime} \mathrm{N}$ & Regular & 220 & 195 & 209 \\
\hline & & $92^{\circ} 3$ I'04.I" E & & & & \\
\hline \multirow[t]{2}{*}{17} & Hawaithang & $24^{\circ} 32^{\prime} 08.9^{\prime \prime} \mathrm{N}$ & Irregular & 24 & 32 & 0 \\
\hline & & $92^{\circ} 48^{\prime} 36.5^{\prime \prime} \mathrm{E}$ & & & & \\
\hline \multirow[t]{2}{*}{18} & Hawaithang West & $24^{\circ} 3 I^{\prime} 52.8^{\prime \prime} \mathrm{N}$ & Irregular & 46 & 30 & 0 \\
\hline & & $92^{\circ} 48^{\prime} 29.8^{\prime \prime} \mathrm{E}$ & & & & \\
\hline \multirow[t]{2}{*}{19} & Jodonpur & $24^{\circ} 32^{\prime} 18.8^{\prime \prime} \mathrm{N}$ & Regular & 70 & 86 & 80 \\
\hline & & $92^{\circ} 48^{\prime} 36.3^{\prime \prime} \mathrm{E}$ & & & & \\
\hline \multirow[t]{2}{*}{20} & Jogodishpur PartV & $24^{\circ} 54^{\prime} 17.6^{\prime \prime} \mathrm{N}$ & Regular & 380 & 350 & 206 \\
\hline & & $92^{\circ} 33^{\prime} 31.1 \mathrm{l} \mathrm{E}$ & & & & \\
\hline \multirow[t]{2}{*}{21} & Kanakpur (Jaipur) & $24^{\circ} 53^{\prime} 04 . I^{\prime \prime} \mathrm{N}$ & Regular & 70 & 59 & 83 \\
\hline & & $93^{\circ} 04^{\prime} 02.6^{\prime \prime} \mathrm{E}$ & & & & \\
\hline \multirow[t]{2}{*}{22} & Kuriabasti & $24^{\circ} 48^{\prime} 59.3^{\prime \prime} \mathrm{N}$ & Regular & 320 & 287 & 212 \\
\hline & & $92^{\circ} 40^{\prime} 47.7^{\prime \prime} \mathrm{E}$ & & & & \\
\hline \multirow[t]{2}{*}{23} & Laikon Basti & $24^{\circ} 46^{\prime} 24.8^{\prime \prime} \mathrm{N}$ & Irregular & 52 & 23 & 13 \\
\hline & & $92^{\circ} 58^{\prime} \mid 5.4^{\prime \prime} \mathrm{E}$ & & & & \\
\hline \multirow[t]{2}{*}{24} & Madhabbari & $24^{\circ} 52^{\prime} 28.4^{\prime \prime} \mathrm{N}$ & Tree cuting & 58 & 42 & 0 \\
\hline & & $92^{\circ} 52^{\prime} 46.1 \mathrm{l} \mathrm{E}$ & & & & \\
\hline \multirow[t]{2}{*}{25} & Masughat & $24^{\circ} 5 I^{\prime} 31.0^{\prime \prime} \mathrm{N}$ & Tree cuting & 120 & 0 & 0 \\
\hline & & $92^{\circ} 46^{\prime} 06.7^{\prime \prime} \mathrm{E}$ & & & & \\
\hline \multirow[t]{2}{*}{26} & Muniarkhal & $24^{\circ} 34^{\prime} 53.3^{\prime \prime} \mathrm{N}$ & Irregular & 64 & 33 & 0 \\
\hline & & $92^{\circ} 57^{\prime} 32.3^{\prime \prime} \mathrm{E}$ & & & & \\
\hline \multirow[t]{2}{*}{27} & Natanpur & $24^{\circ} 56^{\prime} 23.0^{\prime \prime} \mathrm{N}$ & Regular & 160 & 190 & 272 \\
\hline & & $92^{\circ} 33^{\prime} 38.5^{\prime \prime} \mathrm{E}$ & & & & \\
\hline 28 & Puthirkhal, lakhipur & $24^{\circ} 46^{\prime} 35.0^{\prime \prime} \mathrm{N}$ & Tree cuting & 86 & 0 & 0 \\
\hline & & $92^{\circ} 59^{\prime} 08.2^{\prime \prime} \mathrm{E}$ & & & & \\
\hline 29 & Rajnagar (Pailapool) & $24^{\circ} 5 \mathrm{I}^{\prime} 29.6^{\prime \prime} \mathrm{N}$ & Regular & 180 & 160 & 224 \\
\hline
\end{tabular}




\begin{tabular}{|c|c|c|c|c|c|c|}
\hline SI. no & Name of the roosting site & $\begin{array}{l}\text { Geographical coordinates } \\
92^{\circ} 4 I^{\prime} 15.2^{\prime \prime} \mathrm{E}\end{array}$ & Type of roosting & \multicolumn{3}{|c|}{ Number of individuals } \\
\hline \multirow[t]{2}{*}{30} & Rajnagar (Faruk Res) & $24^{\circ} 55^{\prime} 08.2^{\prime \prime} \mathrm{N}$ & Tree cuting & 26 & 0 & 0 \\
\hline & & $92^{\circ} 42^{\prime} 59.7^{\prime \prime} \mathrm{E}$ & & & & \\
\hline \multirow[t]{2}{*}{31} & Rajobari (Jalenga) & $24^{\circ} 49^{\prime} 47.3^{\prime \prime} \mathrm{N}$ & Irregular & 190 & 120 & 62 \\
\hline & & $92^{\circ} 5 \mathrm{I} 33 . \mathrm{Il} \mathrm{E}$ & & & & \\
\hline \multirow[t]{2}{*}{32} & Raninagar & $24^{\circ} 54^{\prime} 30.9^{\prime \prime} \mathrm{N}$ & Regular & 470 & 560 & 723 \\
\hline & & $92^{\circ} 42^{\prime} 45.7^{\prime \prime} \mathrm{E}$ & & & & \\
\hline \multirow[t]{2}{*}{33} & Rengti & $24^{\circ} 47^{\prime} 00.9^{\prime \prime} \mathrm{N}$ & Regular & 380 & 410 & 425 \\
\hline & & $92^{\circ} 45^{\prime} 35 . \mathrm{I} " \mathrm{E}$ & & & & \\
\hline \multirow[t]{2}{*}{34} & Rukni Part I & $24^{\circ} 39^{\prime} 52.8^{\prime \prime} \mathrm{N}$ & Irregular & 62 & 48 & 0 \\
\hline & & $92^{\circ} 52^{\prime} 42.7^{\prime \prime} \mathrm{E}$ & & & & \\
\hline \multirow[t]{2}{*}{35} & Sewti Part I & $24^{\circ} 56^{\prime} 37.2^{\prime \prime} \mathrm{N}$ & Regular & 182 & 152 & 135 \\
\hline & & $92^{\circ} 38^{\prime} 49.1 " \mathrm{E}$ & & & & \\
\hline \multirow[t]{2}{*}{36} & Shivnarayanpur & $24^{\circ} 52^{\prime} 32.4^{\prime \prime} \mathrm{N}$ & Regular & 80 & 146 & 160 \\
\hline & & $92^{\circ} 37^{\prime} 20.9^{\prime \prime} \mathrm{E}$ & & & & \\
\hline \multirow[t]{2}{*}{37} & Silkoorie & $24^{\circ} 46^{\prime} 35.0^{\prime \prime} \mathrm{N}$ & Irregular & 76 & 56 & 0 \\
\hline & & $92^{\circ} 59^{\prime} 08.2^{\prime \prime} \mathrm{E}$ & & & & \\
\hline \multirow[t]{2}{*}{38} & Manipuribasti, Jalenga & $24^{\circ} 52^{\prime} 28.4^{\prime \prime} \mathrm{N}$ & Regular & 260 & 234 & 183 \\
\hline & & $92^{\circ} 52^{\prime} 46 . I^{\prime \prime} \mathrm{E}$ & & & & \\
\hline \multirow[t]{2}{*}{39} & Sewti Part IV & $24^{\circ} 54^{\prime} 52.7^{\prime \prime} \mathrm{N}$ & Regular & 156 & 160 & 167 \\
\hline & & $92^{\circ} 38^{\prime} 49.9^{\prime \prime} \mathrm{E}$ & & & & \\
\hline \multirow[t]{2}{*}{40} & Suklabaigyapara & $24^{\circ} 40^{\prime} 00.2^{\prime \prime} \mathrm{N}$ & Irregular & 70 & 0 & 0 \\
\hline & & $92^{\circ} 52^{\prime} 49.0^{\prime \prime} \mathrm{E}$ & & & & \\
\hline \multirow[t]{2}{*}{41} & Tulargram & $24^{\circ} 55^{\prime} 08.2^{\prime \prime} \mathrm{N}$ & Regular & 46 & 0 & 0 \\
\hline & & $92^{\circ} 42^{\prime} 59.7^{\prime \prime} \mathrm{E}$ & & & & \\
\hline \multirow[t]{2}{*}{42} & Tupkhana & $24^{\circ} 5 I^{\prime} 25.8^{\prime \prime} \mathrm{N}$ & Regular & 170 & 120 & 86 \\
\hline & & $92^{\circ} 45^{\prime} 57.5^{\prime \prime} \mathrm{E}$ & & & & \\
\hline \multirow[t]{2}{*}{43} & Udharbandh & $24^{\circ} 52^{\prime} 28.4^{\prime \prime} \mathrm{N}$ & Regular & 330 & 278 & 310 \\
\hline & & $92^{\circ} 52^{\prime} 46 . I^{\prime \prime} \mathrm{E}$ & & & & \\
\hline \multirow[t]{5}{*}{44} & Ujangram & $24^{\circ} 52^{\prime} 38.9^{\prime \prime} \mathrm{N}$ & Regular & 90 & 56 & 31 \\
\hline & & $92^{\circ} 44^{\prime}$ I $8.4^{\prime \prime} \mathrm{E}$ & & & & \\
\hline & & Grand total & & 6370 & 5403 & 5033 \\
\hline & & Mean roosting size & & 144.77 & 122.79 & 114.38 \\
\hline & & $($ mean $\pm \mathrm{SE})$ & & \pm 1.72 & \pm 1.79 & \pm 1.85 \\
\hline
\end{tabular}

\section{Conservation status}

Currently, the Short-nosed Fruit Bat has been classified 'Least Concern' under the IUCN red list (Version 3.1) category and declared as the species to have an increasing trend of population. As per Wildlife protection (act) 1972, this species falls under scheduled V. However this bat species has not been listed in CITES.

\section{Population status}

Population estimation of Cynopterus sphinx documented 297 individuals in the year 2013, 231 individuals in the year 2014 and 221 individuals in the year 2015. The mean population size of Cynopterus species during the study period was calculated as $27 \pm 0.89$ (mean \pm $\mathrm{SE}, \mathrm{n}=11), 21 \pm 0.98($ mean $\pm \mathrm{SE}, \mathrm{n}=11)$ and $20 \pm 1.91$ (mean $\pm \mathrm{SE}$, $\mathrm{n}=11$ ) (Table 2).

Cynopterus sphinx is a foliage living species and maintains a group of 3 to 8 individuals (Figure 2/B). During present study a total of 11 palm trees (Borassus flabellifer) were detected with 2-9 groups in each tree having 8-51 individuals. The individuals in highest number were documented among all the roosting site for C. sphinx in the year of 2013 was Kumbhirgram (47) while the minimum was in Kajalbasti (17). In the year 2014, the maximum number of individual was recorded in Arunabandh tea estate (39) and the minimum 
was recorded in Gumra Khelma Part-IV (8). In the year 2015, the maximum individual counted in Islamabad (51) while the minimum was recorded for Rukni Part-II (9). During the study period, 2 roosting

Table 2 C. sphinx observed in different sites of Cachar District locations were documented having increasing number of individual while the rest were observed maintaining the decreasing rate of the individuals.

\begin{tabular}{|c|c|c|c|c|c|c|}
\hline \multirow[t]{2}{*}{ SI. no } & \multirow[t]{2}{*}{ Name of the roosting site } & \multirow[t]{2}{*}{ Geographical coordinates } & \multirow[t]{2}{*}{ Type of roosting } & \multicolumn{3}{|c|}{$\begin{array}{l}\text { Number of individuals in each } \\
\text { tree }\end{array}$} \\
\hline & & & & 2013 & 2014 & 2015 \\
\hline \multirow[t]{2}{*}{1} & Muniarkhal Tea Estatae & $24^{\circ} 34^{\prime} 35.3^{\prime \prime} \mathrm{N}$ & Regular & 22 & 17 & 12 \\
\hline & & $92^{\circ} 57^{\prime} 00.8^{\prime \prime} \mathrm{E}$ & & & & \\
\hline \multirow[t]{2}{*}{2} & Shalgonga & $24^{\circ} 55^{\prime} 00.5^{\prime \prime} \mathrm{N}$ & Regular & 31 & 18 & 17 \\
\hline & & $92^{\circ} 57^{\prime} 04.0^{\prime \prime} \mathrm{E}$ & & & & \\
\hline \multirow[t]{2}{*}{3} & Kumbhirgam & $24^{\circ} 54^{\prime} 48.4^{\prime \prime} \mathrm{N}$ & Regular & 47 & 36 & 28 \\
\hline & & $92^{\circ} 58^{\prime} 28.2^{\prime \prime} \mathrm{E}$ & & & & \\
\hline \multirow[t]{2}{*}{4} & Arunabandh Tea Estate & $24^{\circ} 53^{\prime} 58.6^{\prime \prime} \mathrm{N}$ & Regular & 36 & 39 & 46 \\
\hline & & $92^{\circ} 55^{\prime} 06.5^{\prime \prime} \mathrm{E}$ & & & & \\
\hline \multirow[t]{2}{*}{5} & Rukni Part II & $24^{\circ} 38^{\prime} 35.2^{\prime \prime} \mathrm{N}$ & Regular & 17 & 13 & 9 \\
\hline & & $92^{\circ} 52^{\prime} 24.5^{\prime \prime} \mathrm{E}$ & & & & \\
\hline \multirow[t]{2}{*}{6} & Islamabad & $24^{\circ} 33^{\prime} 18 . I^{\prime \prime} \mathrm{N}$ & Regular & 23 & 35 & 51 \\
\hline & & $92^{\circ} 50^{\prime} 31.6^{\prime \prime} \mathrm{E}$ & & & & \\
\hline \multirow[t]{2}{*}{7} & Gumra Khelma VI & $24^{\circ} 58^{\prime} 44.3^{\prime \prime} \mathrm{N}$ & Irregular & 21 & 8 & 12 \\
\hline & & $92^{\circ} 3 I^{\prime} \mid 2.8^{\prime \prime} \mathrm{E}$ & & & & \\
\hline \multirow[t]{2}{*}{8} & Simultola & $24^{\circ} 54^{\prime} 29.7^{\prime \prime} \mathrm{N}$ & Regular & 29 & 23 & 17 \\
\hline & & $92^{\circ} 40^{\prime} 23.7^{\prime \prime} \mathrm{E}$ & & & & \\
\hline \multirow[t]{2}{*}{9} & Kajalbasti & $24^{\circ} 49^{\prime} 31.6^{\prime \prime} \mathrm{N}$ & Irregular & 19 & 14 & 12 \\
\hline & & $93^{\circ} 06^{\prime} 56.8^{\prime \prime} \mathrm{E}$ & & & & \\
\hline \multirow[t]{2}{*}{10} & Dharamkhal & $24^{\circ} 34^{\prime} 37 . I^{\prime \prime} \mathrm{N}$ & Irregular & 22 & 16 & 17 \\
\hline & & $92^{\circ} 56^{\prime} 56.9^{\prime \prime} \mathrm{E}$ & & & & \\
\hline \multirow[t]{5}{*}{11} & 16 Nombor basti & $24^{\circ} 38^{\prime} 59.1 " \mathrm{~N}$ & Irregular & 30 & 12 & 0 \\
\hline & & $92^{\circ} 50^{\prime} 30.5^{\prime \prime} \mathrm{E}$ & & & & \\
\hline & & & Total & 297 & 231 & 221 \\
\hline & & Mean individual (mean $\pm \mathrm{SE})$ & & 27 & 21 & 20.09 \\
\hline & & & & \pm 0.89 & \pm 0.98 & \pm 1.91 \\
\hline
\end{tabular}

\section{Eonycteris spelaea Dobson, I 87 I (the cave nectar bat)} Morphology

The eyes of Cave nectar-feeding bat are large and have a long reversible tongue with papillae on it. The ears are simple with no ear border and tragus is absent. Belly is pale in colour and the dorsal pelage is dark brown. Neck of the adult males has a fur collar and is darker than the rest of the body whereas the females bear scrubby hairs rounding their neck. The forearm and head-body length of adult bat usually measure $6-7.9 \mathrm{~cm}$ and $8.5-12.5 \mathrm{~cm}$ respectively. The body weight for males varies from 55.0-82.0gram and of female from 35.078.0gm (Figure 2/D).

\section{Conservation status}

The Cave Nectar Bat has been categorized as the least concern species under the Red list category of IUCN (Version 3.1) and it is mentioned that the species has the available population, not declining in a notable manner as compared to the other bat species. As per Indian Wildlife (Protection) Act, 1972, the species falls under Schedule V. However Bumrungsri et al. ${ }^{42}$ found the species is decreasing in number in Thailand whereas Mickleburgh et al. ${ }^{43}$ marked cave tourism and collection the bat for bushmeat as the common threat to the cave nectar bats that belong to Southeast Asia.

\section{Population status}

The study also estimates the population of Eonycteris spelaea in the study area which documented maximum in Bororodmukh $(600+)$ and minimum in Sotorodmukh (400+) (Table 3).

\section{Pipistrellus coromandra, gray I838 (the Indian pipis- trelle)}

\section{Morphology}

The wing membrane of Indian pipistrelle bat is naked and mid to dark brown in colour. The brown ear is triangular in shape while 
the tip is round. Anterior portion is generally dark-brown in colour ranging from chestnut to clove brown while the posterior surface pale or beige brown. ${ }^{44}$ The forearm and of adult Pipistrellus coromandra usually measure $2.5-3.4 \mathrm{~cm}$ while head-body length measure 3.4$4.9 \mathrm{~cm}$ respectively. ${ }^{41}$ The average body weight varies between 3 6gram (Figure 2/B).
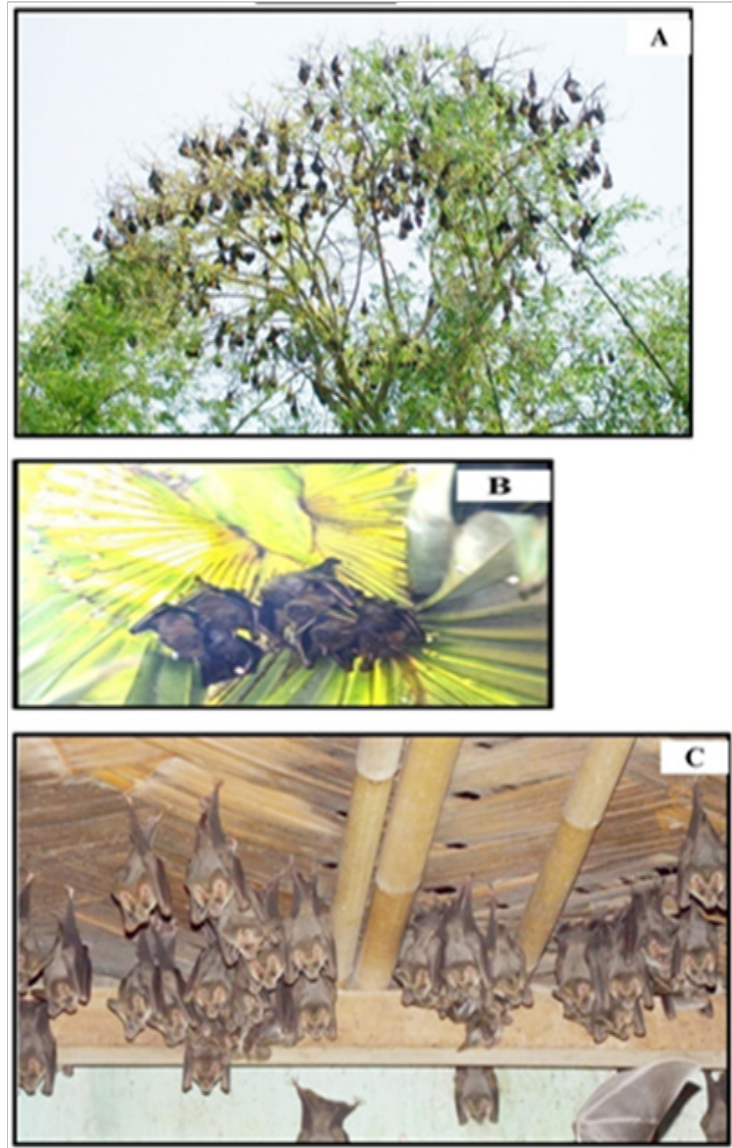

Figure 3 Roosting colony and groups of bats A, Pteropus giganteus; B, Cynopterus sphinx; C, Megaderma lyra.

Table 3 E. spelaea observed in different sites of Cachar District

\section{Conservation status}

The Indian Pipistrelle bat is categorised as the least concern species by IUCN and declared its current population trend as "unknown". However this species of bat has not been listed in Indian Wildlife (Protection) Act, 1972 as well as in the CITES appendices.

\section{Population status}

During the study we checked 10 randomly selected villages. In all places the species was available (Table 4). The group size for $P$. coromandra was recorded as 3 to 5 individuals in the study area. Population estimation of Pipistrellus coromandra was also calculated for the year 2013 which reveals a mean group size of $6.5( \pm 0.46)$. The present study documented maximum individuals in Rosekandy (9) and minimum in Katakhal (3). During present study the individuals were observed to stay both in solitary as well as in group. The lowest group size ranged between three to six individuals.

\section{Megaderma lyra geoffroy, I 8 I 0 (the greater false vam- pire bat)}

\section{Morphology}

The Greater False Vampire bat can be distinguished by the large and straight nose leaf with a rounded base which is extended up to the above line of the eye. Ear are large, joined and fringed with white hair (Figure 2/E). The eyes are small while the face is bearded and a naked snout on it. The Greater false vampire bat poses a large body as compared to most of the insectivorous bats. The belly is whitish in colour while the colour of the body is grayish brown with a paler underside. Body colour of young bat is darker than adults. The forearm and head-body length of adult Greater false vampire bat usually measure $6.5-7.2 \mathrm{~cm}$ and $6.5-9.5 \mathrm{~cm}$ respectively. The body weight varies from 40.0-60.0gram. (Figure 3/C)

\section{Conservation status}

In view of the widespread distribution of the species the Red list category of IUCN (Version 3.1), has categorized the Greater false vampire bats as the least concern species but the current population trend remains unknown. However, this species of bat has not been listed in Indian Wildlife (Protection) Act, 1972.

\begin{tabular}{|c|c|c|c|c|c|}
\hline SI No & Locality & Coordinates & & No. of individuals & Mean \\
\hline I & Soto Rodmukh & $24^{\circ} 38^{\prime} 58.4^{\prime \prime} \mathrm{N}$ & $93^{\circ} 0 I^{\prime} \mid 9 . I^{\prime \prime} \mathrm{E}$ & 400 & 500 \\
\hline \multirow[t]{2}{*}{2} & Boro Rodmukh & $24^{\circ} 38^{\prime} 53.3^{\prime \prime} \mathrm{N}$ & $93^{\circ} 0 I^{\prime} 20.8^{\prime \prime} \mathrm{E}$ & 600 & \\
\hline & & & & 1000 & \\
\hline
\end{tabular}

Table 4 P. coromandra observed in different sites of Cachar District

\begin{tabular}{|c|c|c|c|c|}
\hline SI no & Locality & Coordinates & No. of individuals & Mean \\
\hline \multirow[t]{2}{*}{ I } & Dargakona & $24^{\circ} 4 I^{\prime} 59.5 I^{\prime \prime} \mathrm{N}$ & 8 & $6.5 \pm 0.46$ \\
\hline & & $92^{\circ} 45^{\prime} \mid 8.8^{\prime \prime} \mathrm{E}$ & & (mean $\pm \mathrm{SE}$ ) \\
\hline \multirow[t]{2}{*}{2} & Hathitilla & $24^{\circ} 42^{\prime} \mid 4.2 I^{\prime \prime} \mathrm{N}$ & 7 & \\
\hline & & $92^{\circ} 44^{\prime} 06.5^{\prime \prime} \mathrm{E}$ & & \\
\hline \multirow[t]{2}{*}{3} & Rosekandy & $24^{\circ} 4 I^{\prime} 44.03^{\prime \prime} \mathrm{N}$ & 9 & \\
\hline & & $92^{\circ} 42^{\prime} 38.7^{\prime \prime} \mathrm{E}$ & & \\
\hline \multirow[t]{2}{*}{4} & Silcorie & $24^{\circ} 43^{\prime} 26.83^{\prime \prime} \mathrm{N}$ & 5 & \\
\hline & & $92^{\circ} 47^{\prime} 07.2^{\prime \prime} \mathrm{E}$ & & \\
\hline 5 & Sonabarighat & $24^{\circ} 45^{\prime} 29.53^{\prime \prime} \mathrm{N}$ & 8 & \\
\hline
\end{tabular}




\begin{tabular}{|c|c|c|c|c|}
\hline SI no & Locality & Coordinates & No. of individuals & Mean \\
\hline & & $92^{\circ} 50^{\prime} 02.9^{\prime \prime} \mathrm{E}$ & & \\
\hline \multirow[t]{2}{*}{6} & Sildubi & $24^{\circ} 43^{\prime} 01.29^{\prime \prime} \mathrm{N}$ & 9 & \\
\hline & & $92^{\circ} 49^{\prime} 16.8^{\prime \prime} \mathrm{E}$ & & \\
\hline \multirow[t]{2}{*}{7} & Ramnagar & $24^{\circ} 53^{\prime} 04.95^{\prime \prime} \mathrm{N}$ & 5 & \\
\hline & & $92^{\circ} 45^{\prime} 56.4^{\prime \prime} \mathrm{E}$ & & \\
\hline \multirow[t]{2}{*}{8} & Pailapool & $24^{\circ} 49^{\prime} 53.09^{\prime \prime} \mathrm{N}$ & 4 & \\
\hline & & $93^{\circ} 0 I^{\prime} 51 . I " \mathrm{E}$ & & \\
\hline \multirow[t]{2}{*}{9} & Kamranga & $24^{\circ} 5 \mathrm{I}^{\prime} 27.70^{\prime \prime} \mathrm{N}$ & 7 & \\
\hline & & $93^{\circ} 03^{\prime} 37.1 " \mathrm{E}$ & & \\
\hline \multirow[t]{2}{*}{10} & Katakhal & $24^{\circ} 38^{\prime} 41.77^{\prime \prime} \mathrm{N}$ & 3 & \\
\hline & & $92^{\circ} 50^{\prime} 34.5^{\prime \prime} \mathrm{E}$ & & \\
\hline
\end{tabular}

\section{Population status}

The roosting locations of Megaderma lyra hold approximately 1073 individuals in the year 2013 which came down to 853 (in 2014) and 543 (in 2015). The mean population size M. lyra was found as $46.65 \pm 1.21$ (mean $\pm \mathrm{SE}, \mathrm{n}=23$ ), 37.08 \pm 1.11 (mean $\pm \mathrm{SE}, \mathrm{n}=23$ ) and $23.61 \pm 1.03$ (mean $\pm \mathrm{SE}, \mathrm{n}=23$ ) (Table 5). Observation on the roosting locations of Megaderma lyra during 2013 revealed that the roosting site (Malugram, Dhalai) provided shelter to maximum (128) number of individuals while minimum (8) number of individuals was recorded

Table 5 M. lyra observed in different sites of Cachar District. ${ }^{47}$ in Silcoorie (Dharamkhal). In the year 2014, highest (91) number of individuals was documented in Dhalai (near bridge) and the lowest (5) was recorded in Silcoorie (Dharamkhal). Natun Ramnagar (Site - I : Pritam's residence) recorded maximum (92) number of individuals while minimum (7) was recorded in Borjalengah Part-I during the year 2015. In the year 2013, the active roost of Megaderma lyra in Cachar was found to be 23 which decreased to 18 (in 2014) and 16 (in 2015). The Greater false vampire bat is a colonial species ((Figure 3/C) and during the present study the number of individuals in a diurnal roost was ranged from 5 to 128 .

\begin{tabular}{|c|c|c|c|c|c|c|}
\hline \multirow[t]{2}{*}{ SI. no } & \multirow[t]{2}{*}{ Name of the roosting site } & \multirow[t]{2}{*}{$\begin{array}{l}\text { Geographical } \\
\text { coordinates }\end{array}$} & \multirow[t]{2}{*}{$\begin{array}{l}\text { Type of } \\
\text { roosting }\end{array}$} & \multicolumn{3}{|c|}{$\begin{array}{l}\text { Number of } \\
\text { individuals }\end{array}$} \\
\hline & & & & $2013 *$ & 2014 & 2015 \\
\hline \multirow[t]{2}{*}{ I } & Baladhan banglow, Jaipur & $24^{\circ} 52^{\prime} 51.80^{\prime \prime} \mathrm{N}$ & Regular & 19 & 11 & 14 \\
\hline & & $93^{\circ} 05^{\prime} \mid 5.70^{\prime \prime} \mathrm{E}$ & & & & \\
\hline \multirow[t]{2}{*}{2} & Binnakandi Model H.S. School & $24^{\circ} 42^{\prime} 26.75^{\prime \prime} \mathrm{N}$ & Regular & 39 & 27 & 31 \\
\hline & & $92^{\circ} 58^{\prime} \mid 9.37^{\prime \prime} \mathrm{E}$ & & & & \\
\hline \multirow[t]{2}{*}{3} & Borojalengah (Near block) & $24^{\circ} 40^{\prime} \mid 2.94^{\prime \prime} \mathrm{N}$ & Regular & 48 & 57 & 38 \\
\hline & & $92^{\circ} 43^{\prime} 56.37 " \mathrm{E}$ & & & & \\
\hline \multirow[t]{2}{*}{4} & Borojalengah Part-I & $24^{\circ} 40^{\prime} \mid 2.73^{\prime \prime} \mathrm{N}$ & Regular & 21 & 14 & 7 \\
\hline & & $92^{\circ} 43^{\prime} 38.10^{\prime \prime} \mathrm{E}$ & & & & \\
\hline \multirow[t]{2}{*}{5} & Dhowarbandh H.S. School & $24^{\circ} 36^{\prime} 42.81 " \mathrm{~N}$ & Regular & 43 & 32 & 37 \\
\hline & & $92^{\circ} 43^{\prime}$ I $6.699^{\prime \prime} \mathrm{E}$ & & & & \\
\hline \multirow[t]{2}{*}{6} & Buribail Part - I (R.C.C. culvert) & $24^{\circ} 52^{\prime} 57.12^{\prime \prime} \mathrm{N}$ & Irregular & 21 & 7 & 0 \\
\hline & & $92^{\circ} 4 I^{\prime} 54.87 " \mathrm{E}$ & & & & \\
\hline \multirow[t]{2}{*}{7} & Chandpur (religious place) & $24^{\circ} 59^{\prime} 30.70^{\prime \prime} \mathrm{N}$ & Irregular & 26 & 10 & 0 \\
\hline & & $92^{\circ} 30^{\prime} 21.60^{\prime \prime} \mathrm{E}$ & & & & \\
\hline \multirow[t]{2}{*}{8} & Dhalai (Near Dhalai Bridge) & $24^{\circ} 35^{\prime} 02.92^{\prime} \mathrm{N}$ & Regular & 54 & 91 & 18 \\
\hline & & $93^{\circ} 50^{\prime} 23.14^{\prime \prime} \mathrm{E}$ & & & & \\
\hline
\end{tabular}


Table Continued.

\begin{tabular}{|c|c|c|c|c|c|c|}
\hline \multirow{2}{*}{$\begin{array}{l}\text { SI. no } \\
9\end{array}$} & \multirow{2}{*}{$\begin{array}{l}\text { Name of the roosting site } \\
\text { Dhalai H.S. School }\end{array}$} & \multirow{2}{*}{$\begin{array}{l}\text { Geographical } \\
\text { coordinates } \\
24^{\circ} 35^{\prime} 43.5 \mathrm{I}^{\prime \prime} \mathrm{N}\end{array}$} & \multirow{2}{*}{$\begin{array}{l}\text { Type of } \\
\text { roosting } \\
\text { Regular }\end{array}$} & \multicolumn{3}{|c|}{$\begin{array}{l}\text { Number of } \\
\text { individuals }\end{array}$} \\
\hline & & & & 63 & 51 & 24 \\
\hline & & $92^{\circ} 50^{\prime} 45.68^{\prime \prime} \mathrm{E}$ & & & & \\
\hline \multirow[t]{2}{*}{10} & Dhowarbondh Tillabasti & $24^{\circ} 36^{\prime} 40.12^{\prime \prime} \mathrm{N}$ & Regular & UN & UN & UN \\
\hline & & $92^{\circ} 42^{\prime} 56.89 " \mathrm{E}$ & & & & \\
\hline \multirow[t]{2}{*}{ II } & Eureka English School, Jaipur & $24^{\circ} 52^{\prime} 54.15^{\prime \prime} \mathrm{N}$ & Regular & 62 & 43 & 28 \\
\hline & & $93^{\circ} 03^{\prime} 55.29 " \mathrm{E}$ & & & & \\
\hline \multirow[t]{2}{*}{12} & Jaipur Bridge & $24^{\circ} 52^{\prime} 52.36^{\prime \prime} \mathrm{N}$ & Regular & UN & UN & UN \\
\hline & & $93^{\circ} 04^{\prime} \mid 3.19^{\prime \prime} \mathrm{E}$ & & & & \\
\hline \multirow[t]{2}{*}{13} & Malulgram, Dhalai & $24^{\circ} 37^{\prime}|7.9| " N$ & Regular & 128 & 76 & 0 \\
\hline & & $92^{\circ} 5$ I'03.96"E & & & & \\
\hline \multirow[t]{2}{*}{14} & Natun Ramnagar & $24^{\circ} 42^{\prime} 52.60^{\prime \prime} \mathrm{N}$ & Regular & 72 & 60 & 92 \\
\hline & (Site-I:Pritam's residence) & $92^{\circ} 57^{\prime} 35.60^{\prime \prime} \mathrm{E}$ & & & & \\
\hline \multirow[t]{2}{*}{15} & Natun Ramnagar (Site-II:Engineer's residence) & $24^{\circ} 42^{\prime} 36.46^{\prime \prime} \mathrm{N}$ & Regular & 113 & 83 & 29 \\
\hline & & $92^{\circ} 58^{\prime} 05.49 " \mathrm{E}$ & & & & \\
\hline \multirow[t]{2}{*}{16} & Natun Ramnagar(Site-III: State dispensary) & $24^{\circ} 42^{\prime} 49.70^{\prime \prime} \mathrm{N}$ & Regular & 81 & 62 & 36 \\
\hline & & $92^{\circ} 57^{\prime} 40.00^{\prime \prime} \mathrm{E}$ & & & & \\
\hline \multirow[t]{2}{*}{17} & Palonghat H. S. School & $24^{\circ} 38^{\prime} 47.94^{\prime \prime} \mathrm{N}$ & Regular & 34 & 42 & 27 \\
\hline & & $92^{\circ} 53^{\prime} 09.58^{\prime \prime} \mathrm{E}$ & & & & \\
\hline \multirow[t]{2}{*}{18} & Pangram & $24^{\circ} 54^{\prime} 43.13^{\prime \prime} \mathrm{N}$ & Regular & 77 & 58 & 69 \\
\hline & & $92^{\circ} 54^{\prime} 07.37^{\prime \prime E}$ & & & & \\
\hline \multirow[t]{2}{*}{19} & Puthikhal Medical Sub-centre & $24^{\circ} 39^{\prime} 45.4 I^{\prime \prime} \mathrm{N}$ & Regular & 23 & 17 & 0 \\
\hline & & $92^{\circ} 48^{\prime} 4 I .87^{\prime \prime} \mathrm{E}$ & & & & \\
\hline \multirow[t]{2}{*}{20} & Raja G. C. Memorial H. S. School, Borkhola & $24^{\circ} 55^{\prime} 47.68^{\prime \prime} \mathrm{N}$ & Regular & 58 & 49 & 53 \\
\hline & & $92^{\circ} 44^{\prime} 44.65^{\prime \prime} \mathrm{E}$ & & & & \\
\hline \multirow[t]{2}{*}{21} & Rajnagar, Dhalai (religious place) & $24^{\circ} 13^{\prime} 18.10^{\prime \prime} \mathrm{N}$ & Irregular & 16 & 0 & 0 \\
\hline & & $92^{\circ} 50^{\prime} 59.00^{\prime \prime} \mathrm{E}$ & & & & \\
\hline \multirow[t]{2}{*}{22} & Silcoorie (Dharamkhal) & $24^{\circ} 35^{\prime} 43.5 I^{\prime \prime} \mathrm{N}$ & Irregular & 8 & 5 & 0 \\
\hline & & $92^{\circ} 50^{\prime} 45.68^{\prime \prime} \mathrm{E}$ & & & & \\
\hline \multirow[t]{5}{*}{23} & Sotojalengah & $24^{\circ} 38^{\prime} 53.40^{\prime \prime} \mathrm{N}$ & Regular & 67 & 58 & 40 \\
\hline & & $92^{\circ} 43^{\prime} 00.10^{\prime \prime} \mathrm{E}$ & & & & \\
\hline & & Total & & 1073 & 853 & 543 \\
\hline & & Mean roosting size & & 46.65 & 37.08 & 23.61 \\
\hline & & $($ mean $\pm \mathrm{SE})$ & & \pm 1.21 & \pm 1.11 & \pm 1.03 \\
\hline
\end{tabular}




\section{Scotophilus kuhlii Leach, I82I (the lesser Asiatic yellow house bat) \\ Morphology}

The Lesser yellow house bat is a small bat with a long tail which is covered with a membranous structure called inter femoral membrane between the rear legs. They are easily recognized by the brownish coat on the belly and yellowish brown colour on the back. ${ }^{45}$ The facial structure resembles a dog with a dull muzzle. Ears of the lesser Asiatic yellow house bat are pointy in shape. Forearm and head-body length of adult Scotophilus Kuhlii usually measure $4.7-4.9 \mathrm{~cm}$ and $5.95-6.22 \mathrm{~cm}$ respectively. ${ }^{46}$ The average body weight is about $16 \mathrm{gm}$ (Figure 2C).

\section{Conservation status}

The Lesser yellow house bat is categorised as the least concern species by IUCN and declared as a stable species. However this species of bat has not been listed in Indian Wildlife (Protection) Act, 1972 as well as in the CITES appendices.

\section{Population status}

Observations were made in 7 randomly selected villages for the availability of Scotophilus kuhlii which documented the presence of species in all the villages (Table 6). The population estimation of Scotophilus kuhlii also calculated in the year 2013 revealed a mean individuals of $6.42( \pm 0.77)$. The present study recorded a maximum number of Scotophilus kuhlii in Binnakandi (14) and minimum in Khasiapunji (2) (Table 6).

Table 6 S. kuhlii observed in different sites of Cachar District

\begin{tabular}{|c|c|c|c|c|}
\hline SI no & Locality & Coordinates & $\begin{array}{l}\text { No. of } \\
\text { individuals }\end{array}$ & Mean \\
\hline \multirow[t]{2}{*}{1} & Dargakona & $24^{\circ} 4 I^{\prime} 5.5$ I" N & 7 & $6.43 \pm 0.77$ \\
\hline & & $92^{\circ} 45^{\prime} \mid 8.8^{\prime \prime} \mathrm{E}$ & & $($ mean $\pm S E)$ \\
\hline \multirow[t]{2}{*}{2} & Khasiapunji & $24^{\circ} 52^{\prime} 48.9 I^{\prime \prime} \mathrm{N}$ & 2 & \\
\hline & & $93^{\circ} 06^{\prime} 37.2^{\prime \prime} \mathrm{E}$ & & \\
\hline \multirow[t]{2}{*}{3} & Binnakandy & $24^{\circ} 43^{\prime} \mid 8.9 I^{\prime \prime} \mathrm{N}$ & 14 & \\
\hline & & $92^{\circ} 58^{\prime} 48.1 \mathrm{I} \mathrm{E}$ & & \\
\hline \multirow[t]{2}{*}{4} & Katakhal & $24^{\circ} 38^{\prime} 24.10^{\prime \prime} \mathrm{N}$ & 6 & \\
\hline & & $92^{\circ} 50^{\prime} 37.9^{\prime \prime} \mathrm{E}$ & & \\
\hline \multirow[t]{2}{*}{5} & Sonai & $24^{\circ} 44^{\prime} 04.26^{\prime \prime} \mathrm{N}$ & 9 & \\
\hline & & $92^{\circ} 53^{\prime} 30.8^{\prime \prime} \mathrm{E}$ & & \\
\hline \multirow[t]{2}{*}{6} & Rosekandy & $24^{\circ} 4 I^{\prime} 44.03^{\prime \prime} \mathrm{N}$ & 4 & \\
\hline & & $92^{\circ} 42^{\prime} 38.7^{\prime \prime} \mathrm{E}$ & & \\
\hline \multirow[t]{2}{*}{7} & Sildubi & $24^{\circ} 43^{\prime} 01.29^{\prime \prime} \mathrm{N}$ & 3 & \\
\hline & & $92^{\circ} 49^{\prime} \mathrm{I} 6.8^{\prime \prime} \mathrm{E}$ & & \\
\hline
\end{tabular}

\section{Discussion}

The information presented in this paper is the baseline work and is the first of its kind covering all the herbivorous as well as the insectivorous bat species of Cachar dstrict belonging to one of the most important mammalian order Chiroptera. Mazumdar et al. ${ }^{34}$ reported on the sighting of the three bat species (i.e., Pteropus giganteus, Rousettus leschenaultia and Pipistrellus coromandra) from degraded forest habitat around Assam Univesity, Silchar but the present study did not document $R$. leschenaultia from this region.

Habitat loss in the form of fragmentation, cutting of roosting trees, disturbances at roosting sites and destruction of old structure are considered to be the significant threat to the survival of chiropterans in the study area. The present study documented 37 incidences of habitat loss in or near the roosting sites which cause a tremendous impact on the population of the bat. In many instances, it was observed that people produce smoke using tobacco and dry chilly to drive away bats (Megaderma lyra in particular) from their vicinity. Sometimes they even use fire and kill the species including their siblings. The immediate effect of disturbance to the roost is the evacuation of the roosting place for a short duration but if the disturbance continues for long, bats leave the roost permanently and move elsewhere.

On many instances, it has been observed that people from AssamMizoram border including some local medicine man kill the bats irrespective of the species for consumption as bush meat. Medicine men preach that eating of bat meat would help in curing patients suffering from prolonged asthma. Such concepts have no scientific footings. Again, there are people, who consume bat, as they think it as a good source of protein with some medicinal properties.

Although many tribal communities (Mizo, Tiprai, Tea tribe) involve in consuming bats, there are some other non tribal communities (Hindu, Muslim) who banking on the religious faith, offer community protection and thus help in the survival of bats in the region. The authors have organized a few bat awareness programms in the area. It is also suggested that more and more awareness programs among the communities living adjoining to the roosting site would be of immense help in conserving the chiropterans in the study area in particular and their entire range in general. ${ }^{47}$

\section{Acknowledgements}

The authors are thankful to Assam University, Silchar (India) for allowing in pursuing the work as a part of doctoral research of the first author.

\section{Conflict of interest}

The authors declare that there is no conflict of interests regarding the publication of this paper.

\section{References}

1. Choudhury A. The mammals of India. Gibbon books ISBN9789380652047. 2016.

2. Choudhury A. The Mammals of North-East India. 1st ed. Gibbon Books and the Rhino Foundation for nature. Guwahati, India; 2013. p. 432.

3. Dobson GE. Description of a new Species of the Genus Natalus (Vespertilionidae). Annals and Magigine of Natural History. $1875 ; 16: 260-262$.

4. Koopman KF. Order Chiroptera in Mammal species of the world: a taxonomic and geographic refererence. In: Wilson DE, Reeder DM, editors. Smithsonian Institution Press, Washington, USA; 1993. p. $137-241$.

5. Jones G, Teeling EC. The evolution of echolocation in bats. Trends in Ecology and Evolution. 2006;21(3):149-156.

6. Bussche VRA, Hoofer SR. Phylogenetic relationships among recent chiropteran families and the importance of choosing appropriate out-group taxa. Journal of Mammalogy. 2004;85(2):321-330. 
7. Bats of the world. An introduction to the amazing variety of bats. Bat Conservation Trust, Quadrant House, 250 Kennington Lane, London SE11 5RD, USA; 2015

8. Springer MS, Teeling EC, Madsen O, et al. Integrated fossil and molecular data reconstruct bat echolocation. Proceedings of the National Academy of Sciences. 2001;98(11):6241-6246.

9. Teeling EC, Madsen O, Bussche VRA, et al. Microbat paraphyly and the convergent evolution of a key innovation in Old World Rhinolophoid microbats. Proceedings of the National Academy of Sciences of the USA. 2002;9(3):1431-1436.

10. Bates PJJ, Harrison DL. Bats of the Indian Subcontinent. Harrison Zoological Museum, Sevenoaks, Kent, UK; 1997. p. 258.

11. Srinivasulu C, Srinivasulu B. First record of Hipposideros ater Templeton, 1848 from Andhra Pradesh, India with a description of a new species. Zoos' Print Journal. 2006;21(5):2241-2244.

12. Srinivasulu C, Srinivasulu B, Kaur H, et al. New distribution record and a review on Hipposideros fulvus Gray, 1838 (Mammalia: Chiroptera: Hipposideridae) distribution from Andhra Pradesh, India. Check List. 2013;9(1):139-141.

13. Boro AR, Saikia U, Sikia PK. First report of Saccolaimus saccolaimus Temminck, 1838 (Chiroptera: Emballonuridae) from Assam, northeast India. Small Mammal Mail. 2013;5(1):2-3.

14. Mishra R, Dookia S. Bats of Delhi. Small Mammal Mail. 2015;7(1):15

15. Suthari S, Raju VS. Ecology and conservation status of canebrakes in Warangal District of Andhra Pradesh, India. Journal of Threatened Taxa. 2012;4(15):3426-3432.

16. Purohit A, Senacha KR. Distribution of bats in and around Jaisalmer of the Great Indian Desert, India. Vespertilio. 2004;8:99-104.

17. Saikia U, Sharma RM, Sharma DK. Record of Fulvous Leaf-nosed bat Hipposderos Fulvus Gray, 1838 from Jammu and Kashmir, India. Zoos'Print Journal. 2006;21(3):2197.

18. Balasingh J, Ronald J, Nathan PT, et al. Occurrence of Cynopterus brachyotis (Chiroptera Pteropopidae) in Kalakkad Mundanthurai Tiger Reserve, Southern India. Current Science. 1999;76(12):1542.

19. Shah TS, Srinivasulu C, Kaur H, et al. New distribution records of Tadarida aegyptiaca E. Geoffroy, 1818 (Mammalia: Chiroptera: Molossidae) from Karnataka. International Journal Fauna and Biological Studies. 2014;1(5):41-43.

20. Padmanabhan P. Documentation and conservation of sall mammals in the sacred groves of Kerals, Peninsular India. KFRI research report no: 406, 2005. p. 1-39.

21. Deshpande K, Gangal M, Kelkar N. First record of a bat from the Lakshadweep archipelago, southwestern India. Mammalia. 2015;80(2).

22. Mandal AK, Poddae AK, Bhattacharyya TP. Records of Megaerops niphanae yenbutra and felten, 1983 (Mammalia: Chiroptera: Pteropodidae), Hipposideros lankadiva kellert, 1850 and Hipposideror armiger (Hodgson, 1835) (Chiroptera: Rhinolophidae) from Manipur, India, with taxonomic notes. Records of the Zoological Survey of India. 1993;93(3-4):355-359.

23. Nachiketha SR, Sreepada KS. Occurrence of Indian Painted Bat (Kerivuola picta) in dry deciduous forests of Mudumalai Tiger Reserve, Southern India. Small Mammal Mail. 2013;5(1):16-17.

24. Basumatary SK, Bera SK. Modern pollen record on bat guano deposit from Siju Cave and its implication to palaeoecological study in South Garo Hills of Meghalaya, India. Journal of Cave and Karst Studies. 2014;76(3):173-183.

25. Mandal AK, Poddar AK, Bhattacharyya TP. Further new records of bats from Mizoram, India. Records of the Zoological Survey of India. 2000;98(2):147-154.
26. Murthy MVK, Predeep M, Harshavardhan J, et al. Biodiversity of bats in Mysore city. Journal of Environmental Sciense, toxicology and food technology. 2014;8(11):2319-2402.

27. Srivastava JP, Mandal AK, Biswas DK. New records of Bats from Nagaland, India. Records of the Zoological Survey of India. 2000;98(4):83-87.

28. Sinha YP. The Bats of Rajasthan; Taxonomy and Zoogeography. Records of the Zoological Survey of India. 1980;76:7-63.

29. Ghose RK, Ghosal DK. Record of the Fulvous Fruit Bat, Rousettus lesehenaulti (Desmarest, 1820) from Sikkim, with notes on its interesting feeding habits and status. Journal of Bombay natural History Society. 1984;81:178-179.

30. Debata S, Palei HS, Mohapatra PP, et al. First record of Lesser False Vampire bat (Megaderma spasma, Linnaeus, 1758) from Sundergarh, Odisha, India. Small Mammal Mail. 2013;5(1):26-27.

31. Tangavelou AC, Rani PJ, Karthikeyan S. Conservation of Sacred Indian flying fox (Bat) at sacred landscape of Pudukottai district, Tamil Nadu, India. Asian Journal of Conservation Biology. 2013;2(2):178-180.

32. Majumder J, Majumdar K, Bhattacharjee PP, et al. Inventory of mammals in protected reserves and naturalhabitats of Tripura, northeast India with notes on existingthreats and new records of Large Footed Mouse-eared Bat and Greater False Vampire Bat. Check list. 2015;11(2):1611.

33. Ruedi M, Khlur D, Mukhim B, et al. Discovery of new colonies of the rare Wroughton "s Free-tailed Bat Otomops wroughtoni (Mammalia: Chiroptera: Molossidae) in Meghalaya, northeastern India. Journal of Threatened Taxa. 2014;6(14):6677-6682.

34. Mazumdar K, Soud R, Gupta A. Mammalian Diversity of Degraded Forest Habitats around Assam University Campus, Cachar, Assam, India, with Notes on Conservation Status. Our Nature. 2011;9(1):119-127.

35. Bastawde DB, Mahabal A. Some behavioral aspects of Indian flying fox (Pteropus meanteus simnteus'). Bio - Vigyanam 2 1976;(2):209-212.

36. Thomas DW, Fenton MB, Barclay RMR. Social behaviour of the little brown bat, Myotis lucifugus. I. Mating behaviour. Behavioral Ecology and Sociobiology. 1979;6(2):129-136.

37. Barlow K. Expedition Field Techniques: Bats. Expedition Advisory Centre, Royal Geographical Society (with The Institute of British Geographers) London, UK; 1999. p. 22-30.

38. Thomas DW, Laval RK. Survey and census Methods (Chapter 5), Ecological and Behavioral Methods for the Study of Bats. Washington Smithsonian, USA; 1998. p. 77-89.

39. Vendan SE, Kaleeswaran B, Baskar K, et al. Conservation Status of Indian flying fox, Pteropus giganteus in Tamil Nadu, South India. In: Vikram Reddy M, editor. Wildlife Biodiversity Conservation. Daya Publishers, New Delhi, India; 2008. p. 81-91.

40. Menon V. Indian mammals-A field guide. Hachette Book Publishing India Pvt Ltd, India; 2014

41. Kitchener DJ, Maharadatunkamsi D. Description of a new species of Cynopterus (Chiroptera: Pteropodidae) from Nusa Tenggara, Indonesia. Research Western Australian Museum, Australia; 1991;15:307-363.

42. Bumrungsri S, Harbit A, Benzie C, et al. The pollination ecology of two species of Parkia in southern Thailand. Journal of Tropical Ecology. 2008;24:467-475

43. Mickleburgh S, Waylen K, Racey PA. Bats as bushmeat: a global review. Oryx. 2009;43:217-234. 
44. Smith AT, Xie Y, Hoffmann Rs, et al. A guide to the mammals of China. Princeton University Press, Princeton, USA; 2008. p. 576.

45. Sharma G, Kamalakannan M, Dam D, et al. Status and conservation of Mammalian diveraity in Indian Himalaya. Biological Forum. 2015;6(2):273-299.

46. Srinivasulu C, Racey PA, Mistry S. A key to the bats (Mammalia: Chiroptera) of South Asia. Journal of Threatened Taxa. 2010;2(7):1001-1076.
47. Rahman A, Choudhury P. Status, distribution and roosting habitat of Greater false vampire bat (Megaderma lyra) in Cachar districts of Barak Valley, Assam. In: Dutta BK, Choudhury P, editors. Sustainable biodiversity. 2015. p. 335-342.

48. Van Loon JC. Selected methods of trace metal analysis: Biological and environmental samples. John Wiley and Sons, New York, USA; 1985. p. 365 . 